\title{
STAFF REPRESENTATION RIGHTS RELATED TO THE CREATION OF EMPLOYEE CAPITAL PLANS (PPK)
}

\begin{abstract}
The article presents the role of the staff representation under the Act of 4 October 2018 on Employee Capital Plans. Employee Capital Plans (PPK) are the part of third pillar of polish pension system. By creating the PPK, the legislature placed the staff representation and the employer under an obligation to co-decide on the form of the created capital plan. The method of identifying the staff representation, as defined in the Act on Employee Capital Plans, is modelled on the regulation contained in the Act on Occupational Pension Schemes. The Act on Employee Capital Plans states, that an occupational trade union organisation operating within the premises of the company excludes the competence of representation of employees. The legitimacy of the primacy of the trade union over the non-union representation of the staff stems, first of all, from the possibility of guaranteeing the employees' effective participation in the selection of the financial institution.
\end{abstract}

Keywords: employee capital plans, occupational pension schemes, staff representation, trade union.

\section{UPRAWNIENIA REPREZENTACJI ZALOGI ZWIAZZANE Z TWORZENIEM PRACOWNICZYCH PLANÓW KAPITALOWYCH (PPK)}

Streszczenie. W artykule przedstawiono rolę reprezentacji pracowniczej w świetle ustawy z dnia 4 października 2018 r. o PPK. Pracownicze Plany Kapitałowe (PPK) są częścią trzeciego filaru polskiego systemu emerytalnego. Tworząc PPK, ustawodawca nałożył na reprezentację pracowników i pracodawcę obowiązek współdecydowania o formie tworzonego planu kapitałowego. Sposób wyłaniania reprezentacji załogi, określony w ustawie o pracowniczych planach kapitałowych, wzorowany jest na regulacji zawartej w ustawie o pracowniczych programach emerytalnych. Ustawa o PPK stanowi, że zakładowa organizacja związkowa działająca w podmiocie zatrudniającym wyłącza kompetencje pozazwiązkowej reprezentacji osób zatrudnionych. Zasadność prymatu związku zawodowego nad pozazwiązkową reprezentacją załogi, wynika przede wszystkim z możliwości zagwarantowania stronie zakładowej rzeczywistego udziału w wyborze instytucji finansowej.

Słowa kluczowe: pracownicze plany kapitałowe, pracownicze programy emerytalne, reprezentacja załogi, związek zawodowy.

\footnotetext{
*University of Lodz, Department of Labour Law; marcin.krajewski@wpia.uni.lodz.pl
} 


\section{PRELIMINARY REMARKS}

In Western countries, staff representation plays an important role in the process of creating occupational pension plans. The cooperation of the staff and its hiring entity is the result of a nearly two-hundred-year tradition of creating company forms of old age security (Żukowski 1997, 12). In Poland, the participation of the staff in the creation of the company forms of saving for old age is a relatively new phenomenon, related to the reform of the pension system. By creating the third pillar of that system, the legislature placed the staff representation and the employer under an obligation to co-decide on the company and inter-company occupational pension scheme (PPE). When designing the employee capital plans (PPK), another company form of III pillar saving, the legislator granted the representation of the staff $^{1}$ the power to choose the form of saving and the financial institution that will manage the funds of the PPK contributors.

The objective of the foregoing publication is to indicate the rights of the company trade union organisation and the representation of the company's employees under the Act of 4 October 2018 on Employee Capital Plans (consolidated text Journal of Laws of 2020 item 1342 as amended) and comparing them with the staff rights set out in the Act on Occupational Pension Schemes (consolidated text Journal of Laws of 2020 item 686 as amended).

\section{THE IMPORTANCE OF STAFF REPRESENTATION IN PILLAR III OF THE PENSION SCHEME}

Under the basic pillars, first pillar of the Social Insurance Fund - FUS, the FUS sub-account and the Open Pension Fund - OFE (Jędrasik-Jankowska 2001, 21), the legislator did not provide the opportunity for the hiring entity and the person employed to co-decide on the shape of their retirement pension insurance. The lack of participation of both entities is the result of the public and regulatory nature of the pension contribution (Wantoch-Rekowski 2015, 36) which is the main source of funding for both the FUS and the OFE, as well as the adopted formula for financing the pension - i.e. the financing of pensioners' benefits from contributions from the economically active people of working age (pay-as-you-go method). Benefits from both pillars are covered by a guarantee of payment by the State budget. The public and regulatory nature of the contribution and the formula for financing the pension marginalize the position of the premium payer, limiting it to the role of the one who calculates the amount of the premium and sends it

${ }^{1}$ By this concept, I understand the company staff organization, as well as representation of the employees referred to in art. $7 \mathrm{sec} .3$ and sec. 4 of PrPlKaU. 
to the Social Insurance Fund (FUS). Therefore, neither the insured nor the payer decides on the form of saving for old age, how the premium is multiplied or how the benefit is paid (Krajewski 2014, 220). The exception in this respect relates only to the decision of the insured person to save or not to save in the OFE and, consequently, the decision on the choice made by the insured person regarding an open-end pension fund.

The third pillar of the pension system is distinguished by the voluntary nature of the participation in the pension scheme or the capital plan. The funds collected in the PPE and PPK are provided collectively by the hiring entity and the persons employed. There is no guarantee that the State budget will allow for the future benefits to be paid. The role of the State has been limited to defining the rules for the management of the funds, supervision of the whole system, including in particular financial institutions managing payments to the employee capital plans (PPK), as well as protection of the interest of the participant in the capital plan. Article 51 of PrPlKaU provides that the employee capital plans supervision shall be exercised in the legality and interest of the participants in the capital plan.

The provisions of the Act on Employee Capital Plans and the Act on Occupational Pension Schemes introduce a strictly stipulated register of entities offering these forms of saving for old age. By identifying the list of entities authorised to manage funds in the PPE and the PPK, and by supervising them, the State makes trade union organisation or non-trade union staff representation focus primarily on the criterion of the effectiveness of the various entities offering savings in pillar III (understood as the rate of return of the investment in relation to the costs to be borne by the participants). This is supported by the fact that the legislature, by calculating in Article 7(3) of the PrPlKaU the criteria to be followed when selecting the managing authority for funds in PPK, indicates that it is carried out in particular on the basis of an assessment of the conditions proposed by financial institutions for the management of funds collected in PPK, their effectiveness in the management of those assets and their experience in the management of investment funds or pension funds.

\section{THE CHARACTER OF THE STAFF REPRESENTATION}

When designing the employee capital plans, the legislator had, among other things, to determine the character and the method of selecting the representation of the staff. There were two approaches taken into consideration. First, that the representation established by the group of the employed persons shall be formed outside the trade union organisation, and the second that the operation of the trade union organisation in the company excludes the competence of the non-union representation of the staff - representation of employed persons (Krajewski 2013, 520). The first approach could be supported by the fact that the capital plan should 
be the decision of all potential participants, whether they are members of a trade union or not. The employer, when selecting the representation of the persons employed e.g. convening the staff meeting, is obliged to indicate the suggested financial institution and the conditions for the conduct of the capital plan. After having become acquainted with the suggested conditions, the persons employed may agree, by voting, to enter into an agreement with the hiring entity or may refuse to enter into such an agreement.

A special situation may occur when the representation of the persons employed will consist of one employee or a contractor. It is worth noting that, in accordance with Article 7(1) of PrPlKaU, the obligation to set up a PPK applies also to an entity which employs only one person on behalf of whom it is required to conclude a contract for the operation of the PPK. There are no derogations in this respect. As a result, the hiring entity will agree on the selection of the financial institution with the employed person who shall be entitled to represent the persons employed. In case when the trade union is entitled to enter into the employee capital plan agreement (PPK) or the occupational pension scheme contract (PPE), non-members are deprived of the real possibility of co-deciding on the shape of this form of protection of old age risks. On the other hand, in the case of an employer employing several hundred or more employees, or where part of the crew carries out tasks outside the company's premises, the selection of the representation of the persons employed requires certain logistical procedures slowing down the procedure for concluding the agreement, which may, as a result, significantly impede the selection of the staff representation and the conclusion of an agreement on the selection of the financial institution within the time laid down by law. In such case, negotiations and the conclusion of an agreement with the trade union organisation constitute an essential convenience for the hiring entity.

The Act on Employee Capital Plans states, as is the case under the Occupational Pension Schemes Act, that an occupational trade union organisation operating within the premises of the company excludes the competence of representation of employees. The trade union has a stronger position in negotiations with the employer, which can affect the choice of the financial institution in line with the expectations of the staff, and thus a higher level of participation in the capital plan. It is also important not to underestimate the fact that a trade union organisation can operate in a number of entities and provide an important source of information for the hiring entity at the selection stage of the financial institution or during the negotiation of financial conditions (for example management fees). It is worth noting, however, that in the case of PPK, the conditions for running the capital plan are similar. The maximum level of fees to be paid by PPK participants has been set at a relatively low level and, moreover, the investment of so-called target-date funds averages the investment risk borne by the persons participating in the capital plan (the level of investment risk is reduced in proportion to the age of the PPK participant). The situation of the PPE participant is different, as the 
employer and the financial institution can shape the conditions for running the programme as flexibly as possible, including the level of investment risk.

The method of identifying the staff representation, as defined in the Act on Employee Capital Plans, is modelled on the regulation contained in the Act on Occupational Pension Schemes. It can be argued that it has evolved from employee representation. Article 2(9) of the $1997 \mathrm{PrPrEmU}$ indicated that the employees were represented by the trade union organisation and that, if there was no trade union organisation in the company, the representation of the staff was determined in the manner set out in Article 15(4) of the 1997 PrPrEmU. Pursuant to the aforementioned provision, the non-union representation of the employees was chosen from the staff members during the staff meeting, on the basis and in accordance with the procedure laid down by it (Kopeć, Wojewódka 2005, 77). The main objective of the employee representation was, first of all, to accept or reject an offer to conclude a workforce agreement, that is to say, to agree to create an occupational pension scheme with the employer. If consent was given to the conclusion of the workforce agreement, the staff was represented on behalf of appropriately authorized representatives of the trade union or persons selected by the employer's staff and empowered to conclude an occupational pension scheme on its behalf. The Occupational Pension Schemes Act of 1997 did not specify who, among the persons employed by the employer, was entitled to express the approval or disapproval of creating the PPE. By way of interpretation, that catalogue could be determined on the basis of the concept of worker contained in Article 2(1) of the 1997 PrPrEmU. By means of interpretation, such rights could be determined on the basis of the concept of employee contained in Article 2(1) of the 1997 PrPrEmU. According to the aforementioned provision, an employee was a person employed under an employment contract, contract of appointment, selection or nomination agreement; employed under a cooperative employment contract, an agency contract or a contract of mandate, if covered by social security; employed under a contract concluded as a result of an appointment or election to a body representing a legal person, including a managerial contract.

If there was a trade union organisation operating in the company, it was they who agreed or did not agree to the creation of the PPK. As a result, the decision to create the PPK was taken by persons who were members of the trade union organisation concerned. The right to join trade unions, pursuant to Article 2 of the ZwZawU, was held by employees, regardless of the basis of their employment relationship, members of agricultural production cooperatives and persons working under an agency contract, if they were not employers. In addition, persons engaged in outwork had the right to join trade unions operating within the premises of the hiring entity with which they had established an outwork employment contract. This continued until the amendment to the Trade Union Act, which entered into force on 1 January 2019, (however since June 2015 outworkers have been deprived of their the right to join a trade union). By amending the 
Trade Union Act, the number of persons entitled to join a trade union has been stretched out, and, at present, covers an employee or a person providing paid work on a basis other than an employment relationship if they do not employ other persons for that type of work, irrespective of the basis of employment, having such rights and interests in the performance of work which may be represented and defended by the trade union. According to Article $25^{1}$ of $\mathrm{ZwZawU}$, the rights of a trade union organisation shall be vested in an organisation of at least 10 members who are employees of an employer covered by that organisation or other persons performing gainful employment who have been working for at least 6 months for the employer covered by that organisation.

In 2018, with the introduction of the Act on Employee Capital Programs, the concept of an 'employed person' was introduced. It is correlated, but not the identical, with the concept of employee as defined in the Act on Occupational Pension Schemes. In accordance with Article 2(1)(18) of the PrPlKaU, the term 'employed person' means:

a) the employees referred to in Article 2 of the Act of 26 June 1974; - Labour Code (Journal of Laws of 2020, item 1320 as amended), with the exception of workers on mining leaves and leave for employees of the mechanical coal processing plant referred to in Article 11b of the Act of 7 September 2007 on the operation of coal mining (Journal of Laws of 2019, item 1821), and juvenile workers within the meaning of Article 190(1) of the Labour Code,

b) natural persons engaged in outwork who have completed 18 years of age referred to in the executive regulations to Article $303 \S 1$ of the Labour Code,

c) members of agricultural production cooperatives or agricultural cooperatives associations referred to in Article 138 and Article 180 of the Act of 16 September 1982 - Cooperative Law (Journal of Laws of 2020, item 275, as amended,

d) individuals who have completed 18 years of age, performing work on the basis of an agency contract or a mandate contract or other service contract, to which, in accordance with Article 750 of the Act of 23 April 1964 - Civil Code (Journal of Laws of 2019, item 1145, as amended) the rules on the mandate shall apply,

e) members of board of directors remunerated for the performance of those functions,

f) persons referred to in point a-d on parental leave or receiving maternity or equivalent paternity benefits - subject to compulsory retirement and disability insurance under these titles in the Republic of Poland, within the meaning of the Act of 13 October 1998 on the social security system (Journal of Laws of 2020, item 266, as amended).

It is worth noting that, until the amendment to the Trade Union Act 2019, the personal scope of the concept of an employed person, as used in the Act on Employee Capital Plans, differed significantly from the subjective scope of the 
concept of a person entitled to join a trade union under the Trade Union Act. After the amendment of the Trade Union Act and the granting of the right to join trade unions to persons who provide paid work on a basis other than an employment relationship, the subjective scope of the two terms is similar. It is therefore legitimate to take the view that, in the current legal situation, the choice of a financial institution by both the trade union organisation and the representation of the persons employed gives the warranty of sufficiently extensive consultation with the staff and thus safeguards the interests of future participants in PPK. At the same time, for organisational and logistical reasons, as mentioned above, the primacy of the trade union over the non-union representation of the staff as regards the creation of employee capital plans, should be assessed positively.

\section{RIGHTS OF STAFF REPRESENTATION AT THE STAGE OF THE CREATION OF THE EMPLOYEE CAPITAL PLAN}

The employer has been entrusted with an essential role in the process of creating and operating company forms of old-age security. The scope of its rights depends on the form of the pension plan (scheme) it intends to create. In the case of an occupational pension scheme, the legislator equated the position of the hiring entity and the employee representation. The correspondingly strong position of employee representation is expressed in Article 11 of the PrPrEmU, according to which the workforce agreement is concluded by the employer and the representation of employees. The rejection of an offer by an employee to enter into such agreement means that no occupational pension scheme will be created for the employer concerned. In addition, the legislature decided that the representation of employees would be created by all the trade union organisations operating with the employer concerned. The rejection of an offer to conclude a workforce agreement contract by at least one of the trade union organisations, in principle, makes it impossible to create an occupational pension scheme. However, in order to limit the possibility for an unrepresentative trade union organisation to block the creation of a scheme, provision has been made for the possibility for the hiring entity to repeat an offer of concluding an occupational pension contract and to refer it only to representative trade union organisations within the meaning of the Trade Union Act (Sierocka, 2010, 126). Pursuant to Article 11(8) of PrPrEmU, if, within a period of 2 months from the date on which the employer submits an offer to set up the programme, there is no conclusion of a workforce agreement because the parties cannot agree on its content, the employer may conclude a workforce agreement with representative trade union organisations within the meaning of Article 25 (1) or (2) of the ZwZawU, each of which brings together at least $5 \%$ of the employees employed in the company. As a result, any representative trade union organisation can effectively block the creation of an occupational pension scheme. 
The Act on Employee Capital Plans introduces an obligation to conclude a contract for the management of PPK and thus an obligation for the establishment of PPK by the employing entity. In the event of non-compliance with this obligation, the Polish Development Fund shall invite the hiring entity in writing to conclude, within 30 days of receipt of the request, a contract for the management of PPK with a defined benefit pension fund managed by a designated financial institution, or to provide the PFR with information on the conclusion of a contract for the management of PPK with another financial institution.

By calling for the creation of a PPK and identifying the specific financial institution with which the hiring entity is to conclude a contract for the management of PPK, the legislator has created a regulation that effectively prevents the hiring entity in agreement with the staff representation from effectively blocking or delaying the creation of a capital plan. It should be noted that the creation of PPK entails a significant increase in the cost of employment for the hiring entity. Therefore, the trade union could, in agreement with the employer, deliberately block the creation of a capital plan by negotiating other benefits in return, e.g. pay rise for the staff. It is worth pointing out that, in accordance with Article 106 of the PrPIKaU, if the hiring entity or the person required to act on behalf of the hiring entity does not comply with the obligation to conclude a contract for the management of PPK within the prescribed period, it is liable to a fine of up to $1.5 \%$ of the remuneration fund of the relevant entity in the financial year preceding the commission of the offence.

The staff representation rights defined under the Employee Capital Plans Act are determined by the obligation to create a capital plan by the hiring entity. In view of the voluntary creation of the PPE (e.g. Bagiński 2000, 9), the legislator strengthened the position of the hiring entity and weakened the powers of staff representation. In accordance with Article 7(3) and (4) of the PrPlKaU, the hiring entity shall, in agreement with the staff representation, select a financial institution. The one who initiates the selection of the manager of funds in PPK, i.e. the entity that indicates the financial institution can be both the hiring entity and the representation of the staff. Importantly, in taking a position on the selection of the managing authority for contributions to PPK, the representation of the staff does not by law become a party to the PPK management contract. The parties to this agreement, in accordance with Article 7(2) of the PrPlKaU, shall be the hiring entity and the financial institution authorised to manage the PPK. As a result, the staff representation cannot effectively block the creation of PPK. This is supported by the wording of Article 7(5) of the PrPIKaU. Pursuant to the aforementioned provision, if, one month before the expiry of the period within which the hiring entity is required to conclude a contract for the management of PPK, no agreement has been reached, the hiring entity shall choose the financial institution itself. The entitlement of the hiring entity is defined in the literature as an independent decision-making right (Wojewódka 2020,49). 
The Employee Capital Programs Act does not contain specific rules for consulting the staff representation. Article 7(5) of the PrPlKaU merely specifies that, one month before the expiry of the deadline for concluding the PPK management contract, the hiring entity may conclude a contract for the management of the PPK with the financial institution of its choice, unless an agreement with the crew representation has been already reached. In practice, the period within which the hiring entity carries out consultations should be so defined that the trade union can consult the staff and, once completed, assess the merits of selecting a financial institution from among the designated institution(s) authorised to manage the PPK. On the other hand, where the management entity does not have a trade union organisation and it is necessary to select the representation of the persons employed in the manner adopted in the company, e.g. convening a staff meeting, that period must take account of the need to notify the persons employed, to carry out the necessary consultations and to select the persons empowered to conclude an agreement on the selection of a financial institution. If the crew representation does not take a position, the hiring entity makes the decision to select a financial institution on its own.

A particular case involves a situation where there is more than one trade union organisation operating within the premises of the hiring company. In accordance with Article 7(3) of the PrPlKaU, the hiring entity selects a financial institution in agreement with the trade union organisation operating in that hiring entity. That provision must be interpreted in such a way that the hiring entity concludes an agreement with each trade union organisation operating in the hiring entity concerned. Where an agreement is concluded with certain trade union organisations, Article 7(5) of the PrPIKaU shall apply, which provides that, in the absence of an agreement with a trade union organisation, the hiring entity shall itself select the financial institution and then conclude a contract with it for the management of the PPK.

After the conclusion of the agreement, the hiring entity is obliged to conclude a management contract with the institution designated in agreement with the trade union organisation or the representation of the employees. This is supported by the wording of Article 7(5) of the PrPIKaU, according to which the hiring entity concludes a contract for the management of PPK without the position of crew representation only if it does not reach an agreement with it and at the same time is obliged to conclude a contract for the management of PPK within a period of less than one month.

It is worth noting here that the hiring entity can terminate the PPK management contract on its own and, as a result, lead to a change of financial institution. The PrPlKaU does not, as a general rule, provide for the possibility for the employer to wind up the capital plan and completely abandon this form of saving. In accordance with Article 12(1) of the PrPlKaU, the hiring entity may terminate the PPK management contract if it has concluded a contract for the 
management of PPK with another financial institution run by another investment fund company, Polish Economic Society (PTE), employee pension fund or insurance company. This means, as a consequence, a change in the management of the funds in the PPK. It is worth noting that the legislator introduced a requirement for the cooperation between the employer and employee representation both at the stage of the creation of the capital plan and in the event of a change of the PPK managing authority (Jakubowski, Prusik 2019). Although the law indicates that it is the employer who takes certain actions related to the change of manager and is therefore the one who initiates the change, it is also true that when the financial result achieved by the management entity is unsatisfactory, the trade union organisation may file a non-binding application with the employer asking for a change of the managing institution. Cooperation in this regard is important as it directly affects the number of savers in the amount of future PPK payout.

\section{CONCLUSIONS}

The participation of the staff in the creation of the company's form of old age security is a relatively young phenomenon in Poland. With the implementation of the three-pillar concept of the system, voluntary occupational pension plans were introduced by Western countries. The different philosophy of their functioning, that is to say, the company's nature, the flexibility of the rules for saving for old age, co-financing of the contributions or payments to the scheme, meant that the legislature granted the employee representation the competence to co-decide on the choice of financial institution. It is worth stressing that the involvement of the staff during the programme development phase should mean primarily a high level of participation in the programme.

The legitimacy of the primacy of the trade union over the non-union representation of the staff stems, first of all, from the possibility of guaranteeing the employees' effective participation in the selection of the financial institution. Due to the rights of trade union representatives, the trade union organisation has a greater opportunity to negotiate conditions in line with the crew's expectations. However, it should be made clear that in the case of PPK, there is no classic protection of the interests of the staff known from labour law. The rules for joining the program are regulated in detail by law and secured by sanctions. PPK management agreements and joining the PPK are among the agreements specifically defined by law.

When comparing the rights of staff representation in the Act on Employee Capital Plans and in the Act on Occupational Pension Schemes, it is worth pointing out that PPE is a typical voluntary form of saving for old age. In the case of PPK, there is an obligation to create a capital plan. Considering PPK as a basic form of saving for old age, it is essential that the shape of the structure adopted by the 
employer is approved of by the staff, so that they have an incentive to join the programme.

By creating a regulation requiring the creation of a PPK or enabling of the creation of PPE, the legislature does not correlate it with the regulations governing organisation and joining a trade union.

Under the Occupational Pensions Scheme Act, it was often the trade unions that blocked the creation of the scheme in order to achieve an short-term win in the form of pay rise, rather than a long-term benefit from the PPE. It is also due to the aforementioned reason that the legislature prevented the trade union organisation from blocking the creation of the scheme.

\section{BIBLIOGRAPHY}

Bagiński, Leszek. 2000. Międzyzakładowe pracownicze programy emerytalne. Pracownicze fundusze emerytalne w III filarze. Warszawa: Wydawnictwo Prawnicze.

Jakubowski, Sebastian. Adrian Prusik. 2019. Pracownicze plany kapitałowe. Komentarz. Warszawa: Wolters Kluwer.

Jędrasik-Jankowska, Inetta. 2001. Ubezpieczenie emerytalne. Trzy filary. Warszawa: Wydawnictwa Prawnicze PWN.

Kopeć, Alicja. Marcin Wojewódka. 2005. Pracownicze programy emerytalne. Komentarz. Warszawa: C.H. Beck

Krajewski, Marcin. 2013. "Pozazwiązkowa reprezentacja pracowników jako strona zakładowej umowy emerytalnej". Monitor Prawa Pracy 10: 520-523.

Krajewski, Marcin. 2014. Pracownicze programy emerytalne. Charakterystyka prawna. Łódź: Uniwersytet Łódzki.

Sierocka, Iwona. 2010. Pracownicze programy emerytalne. Białystok: Temida2.

Wantoch-Rekowski, Jacek. 2015. "Składki na ubezpieczenia społeczne w systemie finansowania ubezpieczeń społecznych i w systemie finansów publicznych - wybrane zagadnienia prawnofinansowe“. In Składki na ubezpieczenie społeczne. Edited by Krzysztof Ślebzak. 34-52. Warszawa-Poznań: Zakład Ubezpieczeń Społecznych.

Wojewódka, Marcin. 2020. Ustawa o pracowniczych planach kapitałowych. Komentarz. Warszawa: C.H. Beck

Żukowski, Maciej. 1997. Wielostopniowe systemy zabezpieczenia emerytalnego w Unii Europejskiej $i$ w Polsce. Między państwem a rynkiem. Poznań: Wydawnictwo Akademii Ekonomicznej. 